\title{
Sustainable Tourism in the Open Innovation Realm: A Bibliometric Analysis
}

\author{
Valentina Della Corte ${ }^{1, *}$, Giovanna Del Gaudio ${ }^{1}$, Fabiana Sepe ${ }^{1}$ and Fabiana Sciarelli ${ }^{2}$ \\ 1 Department of Economics, Management, Institutions, University of Naples Federico II, 80126 Naples, Italy; \\ giovanna.delgaudio@unina.it (G.D.G.); fabiana.sepe@unina.it (F.S.) \\ 2 Department of Literary, Linguistics and Comparative Studies, University of Naples Orientale, 80138 Naples, \\ Italy; fsciarelli@unior.it \\ * Correspondence: valentina.dellacorte@unina.it; Tel.: +39-081675370
}

Received: 10 September 2019; Accepted: 25 October 2019; Published: 3 November 2019

\begin{abstract}
This study evaluates bibliometric analysis of sustainable tourism in the open innovation realm, depicts emerging themes, and offers critical discussion for theory development and further research. Through the use of bibliometrix, this paper investigates the amount of studies conducted in this area and verifies if such studies have represented a contribution to the evolving research in the field of sustainable tourism. Specifically, the paper identifies whether and to what extent scholars have explored these interconnections and maps to get to a conceptual structure of the field under investigation. The results identify the development status and the leading trends in terms of impact, main journals, papers, topics, authors, and countries. The analysis and the graphical presentations are crucial, as they can help both researchers and practitioners to better understand the state of the art of sustainable tourism in the experiential and digital era.
\end{abstract}

Keywords: sustainable tourism; sustainable destination; marketing; bibliometrix

\section{Introduction}

In the recent years, tourism has experienced continuous expansion and differentiation that has turned it into one of the economic sectors with greater weight and growth in the world.

In light of the proliferation of literature on the theme under investigation, it appears appropriate to carry out a bibliographical review, based on empirical bibliometric data, in order to find out who are the leading research pioneers interested in studying the theme of sustainable tourism, to discover gaps in our understanding, and redefine new concepts' frontiers.

In particular, this study is intended to fill a gap in the range of bibliometric studies on sustainable tourism produced to date, which have been concentrated in only a few publications, and, for the most part, have approached the issue in a general manner.

In recent decades, growth of the scientific production on the subject has been recorded, and its collection in bibliographic databases has, most insistently, led to the use of "bibliometrics" as a useful tool to measure scientific activity based on the statistical analysis of quantitative data provided by scientific literature.

On one side, a large bibliometric production already exists on the topic of sustainable tourism. For example, [1] used the articles published in a single specialized journal (Journal of Sustainable Tourism) over a period of 15 years for their analysis; [2] carried out a longitudinal analysis of 492 papers published in the four journals of the greatest impact in the field of tourism; and [3] focused on sustainable tourism in sensitive areas, in a first attempt to provide understanding of the accumulated knowledge of the sub-theme by looking at research presented by impact publications. 
The main aim of the paper is to show how the topic of sustainable tourism with its interconnections with marketing activities is developing through a bibliometric analysis that gives very interesting hints and suggestions on future research after presenting an analytic map of the publications over the last 27 years.

The paper is organized as follows: After presenting the methodology, we go through the explanation of intellectual and conceptual, getting to the main findings. The paper ends with its conclusions and hints for further research.

To the best of the authors' knowledge, the sample of this study synthesizes the largest selection of sustainable tourism articles in different journals as the methodology explains.

\section{Literature Review: Sustainable Tourism and Its Interconnections with Experiential and Digital Components in the Era of Open Innovation}

Literature on sustainable tourism has experienced growing expansion in the last decades. Despite this increasing interest in sustainable tourism and its application for the three pillars (environmental, social, and economic), little has been done in terms of systematization of contributions of articles recalling the topic of sustainable tourism and its interconnections with digital and experiential components in the era of open innovation.

Some studies have indeed paid attention to how the topic of sustainability has evolved within the tourism industry.

The study of [4] explores how sustainable restaurant literature within hospitality research has developed from 1991 to 2015. It reveals that scholars concentrate their attention on green aspects of sustainability rather than on economic and social aspects, finally claiming the necessity of a holistic approach.

The research of [5] focuses the attention of ecotourism sustainability conceived from the perspective of marine ecologists. It shows a lack of integration with economic aspects of sustainability. They also highlight the necessity of synergies between ecotourism and productive sectors (fisheries, aquaculture, etc.) that can represent the economic base for the local communities.

As regards the use of bibliometrical analysis for the topic of sustainable tourism, there is an intense production of the literature $[2,6-8]$.

While the study of [2] focuses on the theory, methods, subjects, perspectives/approaches, and geography of scholars used in the articles, the research of [6] mapped the knowledge base on sustainable tourism development from 1990 to 2018. The study presents the core topics of the literature, including "climate change, tourist behaviors and impact, empowerment, policymaking, and the role of cultural heritage in sustainable tourism development" [6].

The study of [7] reveals that the topic is in constant growth, the United States is the leading country on this topic, and the issue of sustainability is strategic for both companies and destinations. In the same direction, [8] show the results of their research identifying the development status and leading trends in terms of impact, main journals, papers, topics, authors, institutions, and countries.

Although bibliometrical studies on sustainable tourism already exist, the attention and novelty of this research lies in the precise topic of sustainable tourism in the digital era, also with specific reference to open innovation and how the use of digital technology can enhance the tourist's experience.

Indeed, nowadays, there is a growing interest in what scholars label as digital sustainability [9-11].

According to [12], "Digital resources are handled sustainably if their utility for society is maximized, so that digital needs of contemporary and future generations are equally met. Digital needs are optimally met if resources are accessible to the largest number and reusable with minimal restrictions". Hence, sustainability is digital when it deals with digital resources.

Among the numerous characteristics of digital sustainability (i.e., intergenerational justice, regenerative capacity, economic use of resources, risk reduction, absorptive capacity, economic and ecological added value [10]), there are some that fit with the interests of sustainable tourism well.

Sharing the idea that digital tools are considered a transversal component of innovation in the tourism sector and not the key component, such as the organizational and experiential [13-15], they 
can enhance the core pillars of sustainability, as they are supportive through their characteristics of economic and ecological added value.

Firstly, digital goods have the feature to be freely available and this characteristic helps tourists obtain free information as in the case of downloading and installing applications for the knowledge of the destination or other tourist attractions [16]. From the ecological point of view, with digital information and communication technology, for example, there is a reduction of printed papers, brochures, or maps [17], and this helps to implement more sustainable practices.

Actually, the vision offered by some scholars $[10,11]$ is reduced if we consider only the digital technology per se without recalling the definition of a tourist product as global and as a result of an overlapping perspective between the demand and offer side [18].

The so called "memorable experience" [19] is also given by the ability of the companies and/or the destination to create a storytelling (demand side perspective) of the places and of the local community that constitute the social humus of the real tourist experience. Through digital tools, destination/companies can tell their stories and digital tourists can use the virtual world to communicate their experiences with other people [20].

The potentiality of storytelling can act on the social pillar of sustainability since it can enhance the visibility of the community in terms of traditions, culture, folklore, and local identity, creating a certain belonging with the community [19].

In this direction, digital sustainability assumes two specific connotations shaped by the holistic perspective of the supply and demand side together. From the demand side, there are digital tourists, like experiencing the destination, attractions and services according to the vision of using digital technologies during their stay [21]. These technologies offer the possibility of increasing the level of immersion within the tourism experience [22].

The interesting aspect, within these issues, is the fact that sustainable tourism has to be conceived in the era of open innovation. The latter, indeed, can impact on the competitiveness of a destination as well as on the aims of sustainability since it can also be defined as "the ability of a destination to create and integrate value added products that help to maintain the position and market share and/or improve it in the long run" [23].

The recall of open innovation is due to the fact that the online open environment allows information about tourists' behaviors to be obtained [24] to create social connections during the tourist experience [25] and to own a certain quantity of data that can have a huge influence on the economic performance of tourist companies [26]. As viewed, these concepts can be connected with the social and economic pillars of sustainability.

Since tourism products are the result of a co-creation approach, the adoption of open innovation can offer added value for tourists and a collaborative basis among the actors of the tourism industry and other stakeholders involved [27-29].

The strength of these opportunities is connected with the fact that open innovation requires the adoption of social big data. This explains how results can be obtained through the leveraging of social networks, favoring relations and involvement among users [27]. These interactions generate ideas and contents for destinations and tourism companies and offer precious advice to enhance experiential components and the sustainability pillars [27].

This is, indeed, the case of open innovation used for the generation of contents through activities of crowdsourcing that exploits the power of user innovation [30].

With specific reference to the tourism sector, another theoretical lens of open innovation is social innovation [31] since different social actors can interact in the process of valuable and innovative tourism products. These actors can also create partnerships of a public-private nature and the implementation of an open innovation approach is useful to improve efficiency and effectiveness [32].

Hence, the ensemble of actors generates the so called "collective intelligence" or "crowd innovation" that "not only produces creative ideas or inventions, but also moderates any firm to innovate inside-out, outside-in, or in a coupled manner" [33]. 
This type of innovation is the source of market open innovation since it overlaps technologies and the knowledge markets [33]. Nowadays, tourism sector requires market open innovation due to the volatility of demand and the hyper competition of the sector.

\section{Methodology}

This paper uses bibliometric analysis [34], which is a methodology largely used in business and management areas [35-37] as well as in tourism $[38,39]$ because it allows a state-of-art of the topic to be explored through research.

Of course, there are different methods to systematize contributions on a specific topic, but the strength of bibliometrix is that it is a systematic, straightforward, and reproducible process. Furthermore, the use of bibliometrical analysis is helpful for avoiding subjectivity.

As regards the relevance of bibliometrics in tourism science, this has already been outlined in a paper published in the Annals of Tourism Research [40], where the authors assert the relevance of this tool in generating non-speculative knowledge. In this case, the study regards the use of statistical methods in tourism research and is longitudinal, since it is carried out on 12 journals published in a 5-year period (1998-2002). The approach has grown as tourism sciences have been developing in terms of specialist literature, and in its links and relationships with general traditional disciplines that have increased its robustness for the scholars [36]. Another strength is that it is a multi-disciplinary science, with multiple theoretical and methodological perspectives [31].

Thus, literature reviews have acquired a significant restructuring to get to bibliometrics, which mainly concentrates on the measurement of properties of documents, and of document-related processes [41,42]. As explained by Benkendorf $(2009$, p. 2), "advances in information technology, and improvements in the coverage of bibliometric databases such as ISI Web of Science (WoS), Scopus and Google Scholar (GS) have seen substantial advances in bibliometric analysis".

The main advantage of bibliometrics is that it combines both evaluative and relational methods, traditionally considered as alternative $[43,44]$. Within bibliometrics, indeed, there are several quantitative relational techniques that use citation data well to further "evaluative counting and ranking of research productivity" [35] and allow visualization of co-citations through social network analysis.

Other contributions also apply it to the study of journal rankings [45]. On this wake, bibliometric analysis has also been used to discuss the epistemology of tourism, in order to get interesting insights within the wide range of tourism interdisciplinary studies in tourism research [46]. These works emphasize that evaluative techniques assess the impact of academic production with reference to performance or scientific contributions of two or more individuals/groups: Authorship analysis [47], citations analysis [48], and use of research knowledge [35], just to cite some. On the other hand, relational techniques study relationships to identify the structure of research areas and new methodological or conceptual trends, mainly through co-authorship and co-citation analysis [36,49]

Some scholars [50] have continued with longitudinal bibliometric analysis with interesting results on geographic areas and research topics, which are useful to analyze future trends and to get hints on the main research areas in tourism.

In the latest years, considering the growing literature and its relative robustness, the research has focused on specific topics, like sustainable tourism [2], rather than adventure tourism [40], or analyzed the impact of some managerial subjects, like finance, on tourism industry, in order to evaluate their relative impact factor [51]. In some cases, like in [39], the authors also combine bibliometric analysis with other techniques, like content analysis and a quantitative literature review. Such an approach is very interesting, since it allows the development of a more analytic study of eventual sub-areas of research that are growing, e.g., those that are understudied and the most relevant topics. Others focus on a long period of scientific production on specific journals. The authors of [52] observed the articles published over time in Tourism and Hospitality Research. Among the main results, a shift from conceptual articles to quantitative studies (research design, surveys) was identified, as well as from case studies and surveys to content analyses. 
This paper focuses on science mapping analysis that shows the existing relationships between disciplines, fields of research, scholars, and papers according to a spatial representation [53].

This paper is structured following a precise protocol of some scholars [25,54]:

1. Data collection;

2. Data analysis and data visualization; and

3. Interpretation.

We performed our analysis through the R-package bibliometrix [55]. This tool is specifically designed for quantitative research in Scientometrics and Bibliometrics. It provides various routines for analysis and supports all the main steps of a classical bibliometric workflow.

We used Web of Science databases (e.g., Social Science Citation Index for Social Science) to search peer-reviewed scientific articles in English in order to study the literature in the specific domain of sustainable tourism. Even if Scopus is another important database, several scholars [56,57] assert that there is a full overlap between the two and WoS remains the one of the highest quality. The following groups of keywords were used for the search:

- Sustainable touris *

- Sustainable destination *

The asterisk indicates that the word includes all the words containing its root as well as in singular and plural form. For example, "touris" can include tourism, tourist, tourists.

The group "sustainable touris*" regards our research topic and the root of the word "touris" was chosen in order to include the aspects of both the supply and demand side. Indeed, the word can be enlarged, for example, as a noun to tourism and tourist/s, or as an adjective to tourism company/firm, etc.

The group of words "sustainable destination*" was included since the destination is the place where the paradigm of sustainability can be fulfilled [58] in the three universally known dimensions (economic, social, and environmental).

To these groups, other words were coupled. These are "experienc*", "digital", and "open innovation" since the framework of sustainable tourism must be conceived in the actual era where the experiential and the digital components as well as the open environment are the milestones of modern tourism [59-61]. Indeed, the binomial concept of digital and experience finds its roots in the assumption that "with technology being embedded within the destinations environment, it can enrich tourist experiences and enhance destinations competitiveness" [62], hence, "providing tourists' satisfaction with high-quality experience while promoting the concept of a sustainable attitude" [63]. These terms appeared in the title, keywords, and abstract. We selected only peer-reviewed papers published in journals belonging to the subject categories "business", "economics", "management", and "operations research and management science". The final collection was shaped by 330 articles.

Particularly, this paper uses some research methods.

Literature trends are displayed through a Pareto diagram that analyzes the frequency of published papers according to a precise lapse of time (1992-2019). Furthermore, to summarize the main results of the bibliometric analysis, the "summary" function shows the main information about several tables. We used it to describe the collection size in terms of the top five journals and of the top cited journals.

A thematic map allows four typologies of themes to be defined according to the quadrant in which they are placed.

Themes in the upper-right quadrant are known as the motor themes. They are characterized by both high centrality and density. This means that they are developed and important for the research field.

Themes in the upper-left quadrant are known as the high developed and isolated themes or niche themes. They have well developed internal links (high density) but unimportant external links and so are of only limited importance for the field (low centrality). 
Themes in the lower-left quadrant are known as emerging or declining themes. They have both low centrality and density meaning that are weakly developed and marginal.

Themes in the lower-right quadrant are known as basic and transversal themes. They are characterized by high centrality and low density. These themes are important for a research field and concern general topics transversal to the different research areas of the field.

The paper also uses co-word analysis using network analysis in order to visualize the conceptual structure in a network of words.

Finally, a historical direct citation network is used as a chronological network map of the most relevant direct citations of the database.

\section{Discussion}

Figure 1 shows the literature trends from 1992 to 2019. The graph demonstrates the explosion of contributions since 2007.

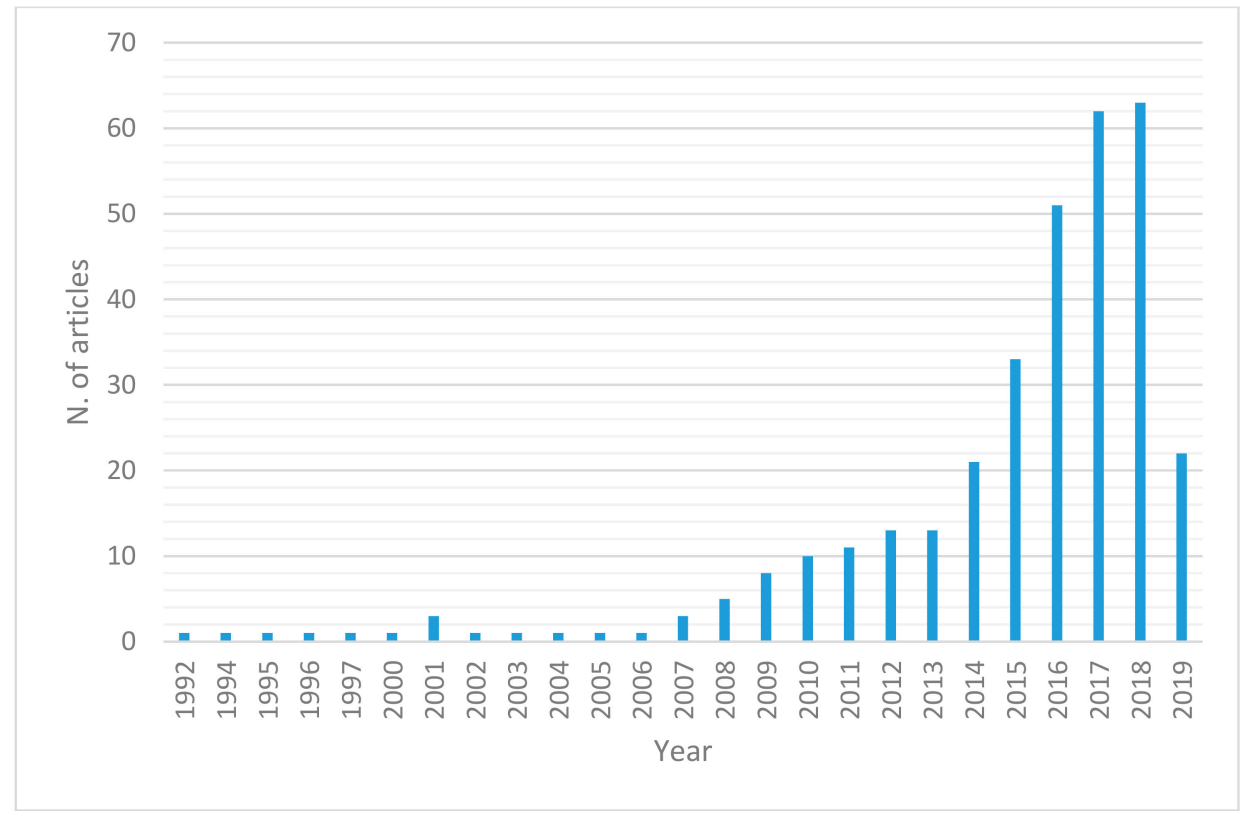

Figure 1. Annual scientific production.

During the first period (1992-2008), the total number of papers is 22. In this period, the first contributions deal with the environmental pillar of sustainability to then enlarge the spectrum to protected areas. Since 2003, the concept of community involvement starts to appear, highlighting the strategic meaning of the local actors in sustainable development. Furthermore, specific topics connected with sustainable tourism development are addressed. This is, for example, the case of sustainable transportation enclosed within the framework of travel chains in order to create a sustainable tourism product according to a holistic way [64-67].

The period 2009-2014 counts 76 papers. Some papers deal with the topic of local food as a sustainable experience [68-71] since it recalls the authenticity of traditions but also has low environmental impact thanks to the use of local raw materials.

Other contributions [72] stress the attention on eco-tourism with the underpinning environmental planning activities and some papers also cite the practice of eco certification [73].

The last years (2015-2019) is the most productive period with 231 contributions. In this period, apart from the traditional topics (i.e., eco-tourism, community involvement, environmental issues, etc.), a wider accent on marketing is given. For example, local food with the lens of responsible exploitation of local resources, is conceived as a sustainable marketing tool [74,75]. Also, the role of digital platforms is afforded since they are participatory tools to enhance stakeholder engagement and 
to co-create new ideas for the destination's sustainable development [76-78]. Moreover, the topic of sustainable tourism is also taken into account in specific industries, such as the hospitality one, and scholars have studied how hotels can be "green" $[79,80]$ to pursue environmental conservation and preservation. Other contributions also deal with the topic of relational marketing and, particularly, on the importance of some activities during tourists' experience [81]. For example, this is the case of local souvenir vendors, who describe the authenticity of a certain place but in some cases, they are substituted by an excessive retail presence [82].

To summarize, the literature trends show a huge production in the latest years and, at the same time, a deeper understanding on different questions of sustainability. Other following elaborations support a more precise comprehension of the topic.

\subsection{Literature Production}

The top five journals have published 135 articles, representing $67 \%$ of the whole collection. As shown in Table 1, this list shows nearly a total prevalence of sector-based journals, basically sustainability and tourism. All these journals are included in the Journal Citation Report@ (JCR) and Scimago. Each journal counts on a high H-index (Hirsch index for the area under study: It is calculated by ranking publications by the number of citations received in descending order, and listing them to determine the point at which the order number matches the number of citations received).

Table 1. Top five journals.

\begin{tabular}{cc}
\hline Sources & Articles \\
\hline Journal of Sustainable Tourism & 67 \\
Sustainability & 27 \\
Tourism Management & 19 \\
Annals of Tourism Research & 15 \\
Tourism Geographies & 7 \\
\hline
\end{tabular}

The journal with the highest number of published articles is the Journal of Sustainable Tourism (H-index: 83) that fits perfectly into the subject of study as, since 1993, it has been the only journal exclusively devoted to sustainable tourism research [1]. Also, other scholars in their reviews have pointed out its importance in the field $[2,6-8,83]$.

Furthermore, we found that not all top-five journals are specialized in a sustainability topic, since other journals included in the table are related to tourism and hospitality research. Specifically, Tourism Management (the journal with highest H-index) publishes a pretty stable number of articles, related to sustainability, with a great impact when observing their citations. This shows us the quality of the journal and its impact; as a matter of fact, the journal occupies the first position in the ranking of the tourism, leisure, and hospitality management category in Scimago (Scopus) and JCR (Journal Citation Reports).

To sum up, this table shows an important result: Articles dealing with sustainability and tourism have not yet been fully explored in more generic journals of business, management, and marketing. This points out a big issue that consists of a huge separation between journals related to specific sectors and those ones that are more general. As underlined by relevant scholars, industry-specific and empirical papers could and should foster theoretical and general concepts in the field. It is also due to the fact that authors who write in general journals often neglect reading articles in more specific but likewise important top journals, even if they are more sector specific.

Furthermore, the bibliometric analysis provides a list of top five most-cited journals (Table 2) where the base of knowledge is also in this case represented by sector-based journals (i.e., Tourism Management, Annals of Tourism Research, Journal of Sustainable Tourism, Journal of Travel Research, Journal of Environmental Psychology). 
Table 2. Most cited journals.

\begin{tabular}{cc}
\hline Sources & Articles \\
\hline Tourism Management & 1240 \\
Annals of Tourism Research & 1128 \\
Journal of Sustainable Tourism & 1107 \\
Journal of Travel Research & 579 \\
Journal of Environmental Psychology & 237 \\
\hline
\end{tabular}

As regards the conceptual structure, bibliometrix uses the thematic map to delineate the conceptual structure of the topic. This latter consists in a word co-occurrence network analysis to defines what science talks about in a field, main themes, and trends.

Thematic mapping [84] allows a visualization of four different typologies of themes as shown in Figure 2. The thematic map exploits he KeyWords Plus field. Those keywords are associated by Thomson Reuters editorial experts supported by a semi-automated algorithm. They review the titles of all references and highlight additional relevant but overlooked keywords that were not listed by the authors. Differently from the authors' keywords, the Keywords Plus field is normalized. Keywords Plus terms are able to capture an article's content with greater depth and variety.

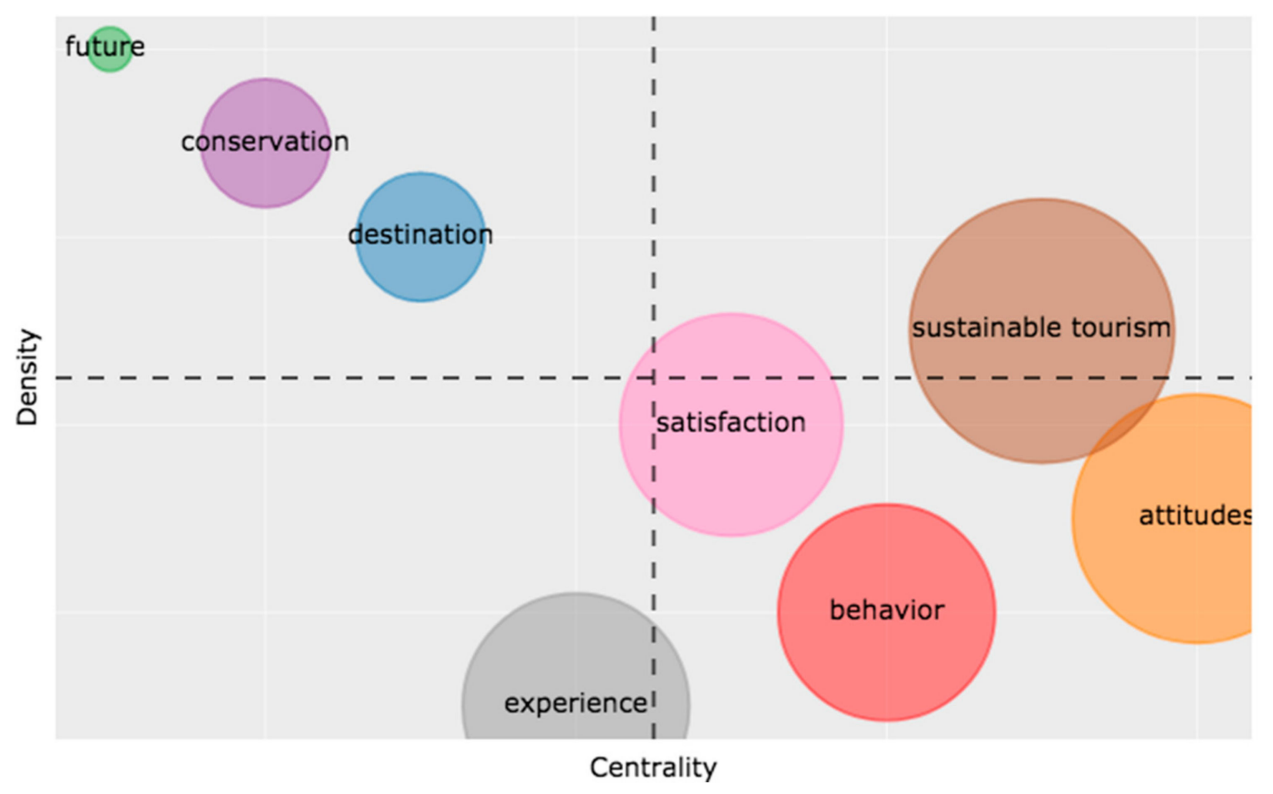

Figure 2. Thematic map.

The upper-right quadrant shows the motor themes. They are characterized by both high centrality and density. Among the "motor themes" that are the more developed in the literature, the main concern is sustainable tourism.

Of course, the motor theme in this analysis is sustainable development. This theme is connected with different concepts, such as performance, authenticity, and China, just to cite some of the many.

As regards the term performance, this is associated to both economic financial performance, customer satisfaction, and process performance. This is one of the most recurring words associated with the cluster sustainable tourism since our initial subject categories were "business", "economics", "management", and "operations research and management science". For these specific categories, economic performance appears as one of the most recurring words even if in some cases this term is referred to as process performance. Indeed, some scholars $[59,60]$ identify certifications as a double tools: One for the internal purpose to reach qualitative standards connected with performance process, the other for external stakeholders (i.e., customers, green associations, controller bodies) in order to communicate the level of environmental sustainability pursued. 
Again, the thematic map also reveals that the term authenticity is connected with the food experience [85]. In these papers [86-88], authenticity always expresses the strategic exploitation of local resources since they have minor environmental impacts but, at the same time, they have two important implications in terms of marketing. The first is connected with the specific tourist products of a certain destination (i.e., the food and beverage tourist product, cultural and heritage tourist product, etc.). The second marketing implication refers to promotion strategy since the communication is concentrated on the aspects of local authenticity. This, indeed, constitutes one strategic factor of differentiation practices and can contribute to the memorability of a place [89]

Within the referring literature, the example of authenticity of culture in its different meanings, handicrafts, dance, music, literature, ceremonies, dress, food [90], authenticity of conventional historical heritage [88], and authenticity of local community [76,77] is highlighted.

With reference to the upper-left quadrant, it shows high density themes but unimportant external links and so are of only limited importance for the field (low centrality).

In this quadrant, it is possible to find the theme of destination since, in the majority of cases, the unit of analysis is constituted by the destination while conservation and future are strictly connected since the concept of sustainability encloses the conservation of resource in order to preserve them for the future and for future generations.

In the lower-left quadrant are the emerging or declining themes. In this research, the theme of experience is emerging, and it is connected again with food, service quality, and place. What is interesting to notice is that one of the most recurring words associated with the theme of experience is "model". The necessity of finding referring models in order to manage sustainable tourism development is claimed within the literature on sustainable destination governance [91-93]. Indeed, a strategic model can suggest the right sustainable management practices.

Finally, the lower-right quadrant shows the themes that are basic and transversal. These themes concern general topics transversal to the different research areas of the field. In this area, the appearing themes are behavior, satisfaction, and attitudes. While the terms behavior and attitudes are used as synonyms, an attitude refers to sustainable conducts enacted by an offer side, demand side, local community, and policy makers; the theme of satisfaction is connected with behavioral intentions, protected areas, and destination image. For sure, the bibliometric analysis shows that the theme of satisfaction is strongly connected with the term experiences since satisfaction is determined by the tourist experience made by authenticity, contact with local community, genuine and local food, etc. [94,95].

\subsection{Density and Centrality of Topics}

In order to understand whether and how the topics of open innovation and sustainable tourism interact with the issues, we first identified within the database 54 papers that are more focused on open innovation and sustainable tourism. Secondly, we used co-word analysis through the network (Figure 3), which shows the conceptual structure between concepts and most recent issues.

One of the most recurring topics is the one of conservation (19) due to the long-term vision and the preservation for future generations. Particularly, the nexus is connected with the nature of some destinations, created by a bottom-up approach, where there is high involvement of local stakeholders. In this field, the conservation of natural areas depends on how the local community and actors of the tourism field interplay [96]. The implementation of an open innovation approach supports the co-creation of sustainable tourism offers [96].

As viewed, the topic of conservation recalls the involvement of a plurality of stakeholders. Indeed, knowledge sharing can have positive impacts on the generation of new value of tourist offers and sustainable tourism products [84]. For example, the cooperation between university centers and entrepreneurs in light of open innovation can favor embeddedness in sustainable tourism that could be replicated in other contexts $[97,98]$.

Of course, another recurring unit of analysis is the destination, demonstrated by the fact that it is the most repeated term $(20+11$ if we consider the word "destination development"). 


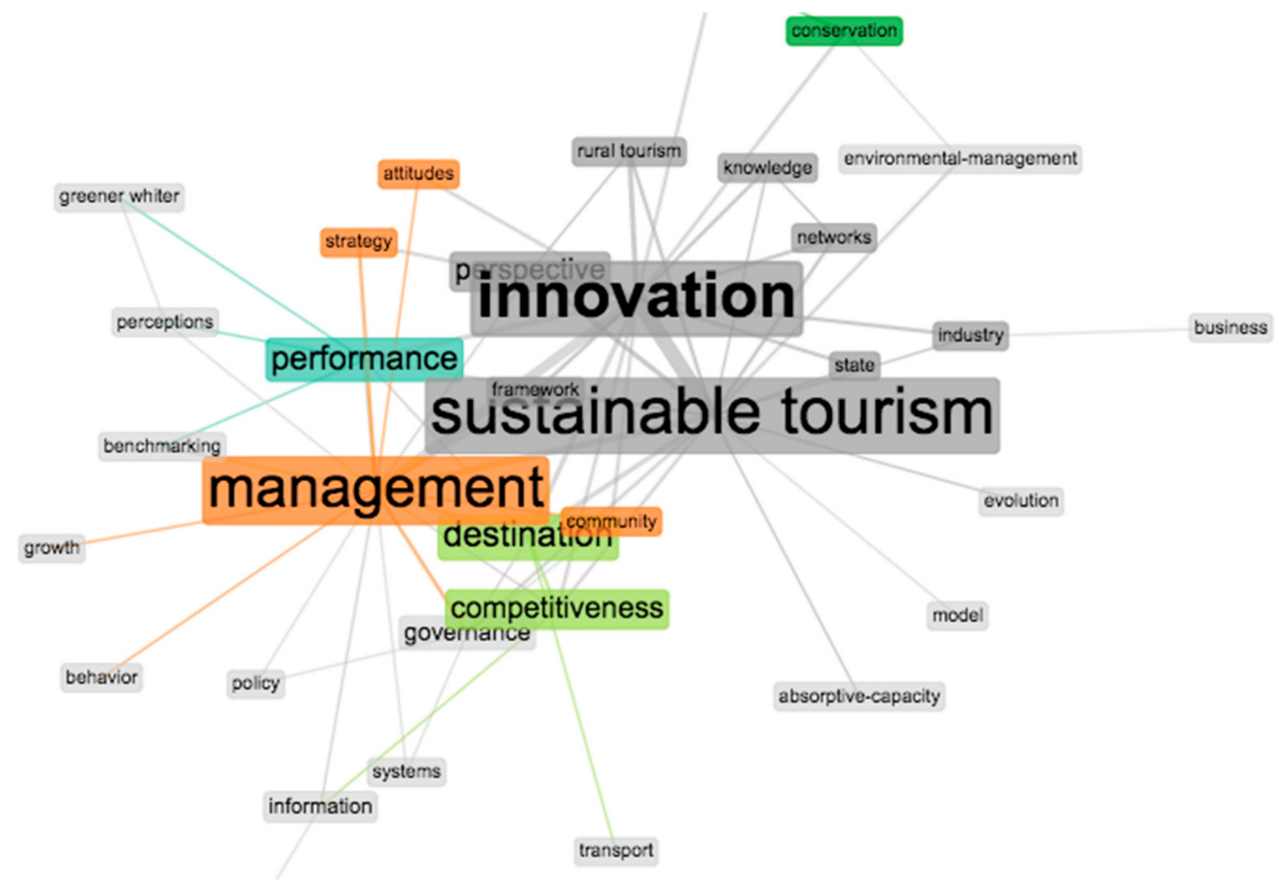

Figure 3. Most recurring issues.

The development of tourism policies to improve sustainability is based on the level of open innovation within the destination. This kind of innovation refers to the plurality of levels shaping the destination, such as the sociocultural, natural, political, legal, and technological [98]. Indeed, the core concept of open innovation is not only the involvement among stakeholders of the destination but also the necessity to innovate at different levels [96]. In this direction, some other issues, as Figure 3 demonstrates, are connected with the destination. This is the case of governance (5), and transportation (13) plays a key role. Destination and its interconnections with sustainability and open innovation are examined according to different perspectives. For example, since one of the main critical factors of the Copenhagen region as well as other destinations is the access (both internal and external mobility), bicycling in urban contexts can be considered a solution thanks to the adoption of an open innovation approach, suggested by some actors as having a high degree of local bicycle culture [99].

\subsection{Co-Word Analysis}

As emerged from the graph, some of the most recurring words are performance (21), management (24), and competitiveness (13). Indeed, scholars question how tourism firms and destinations can achieve the sustainable competitive advantage (from here the terms competitiveness, performance as well as the most generic management) $[100,101]$.

The intellectual structure is developed by a historical direct citation network that deploys a chronological citation network (Figure 4). Indeed, it "represents a chronological map of the most relevant citations resulting from a bibliographic collection" [43]. The interesting aspect of this visualization is not the name of the author/s per se but rather their topics of interest on sustainable tourism and the following debate that scholars open in the scientific field. 


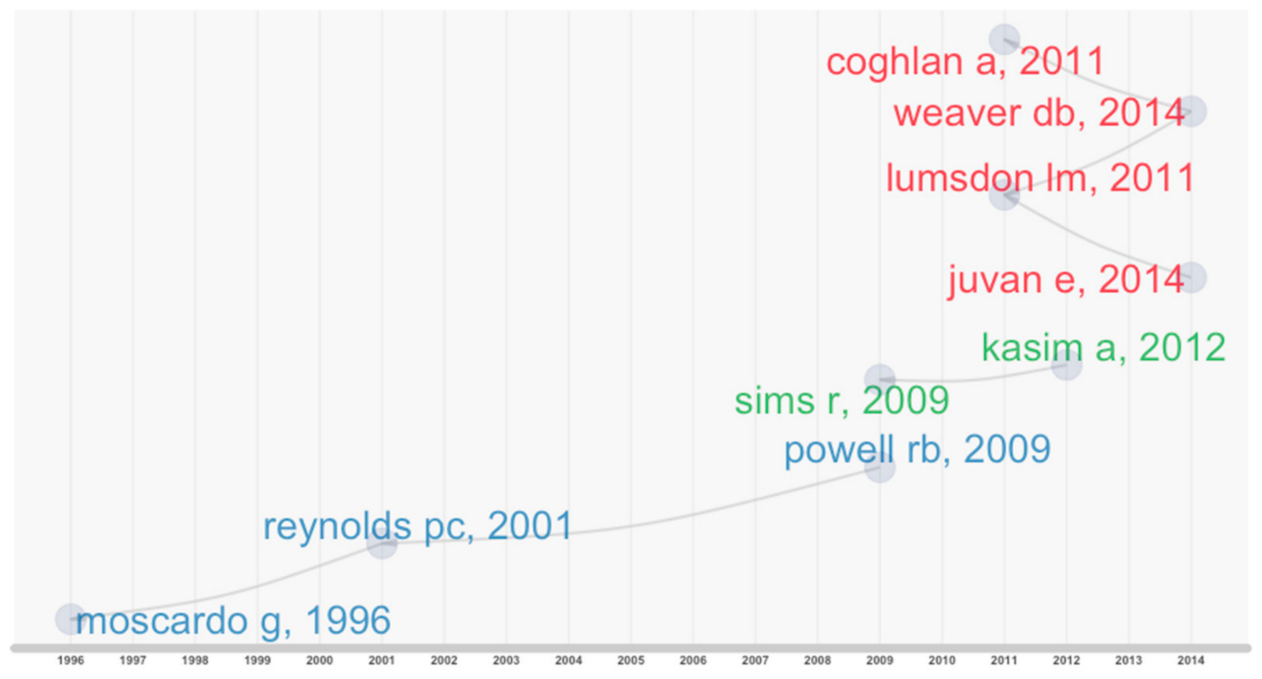

Figure 4. Historical direct citation network.

\subsection{Authors' Citations}

For example, [102] deals with the topic of heritage sites and the necessity of creating overlapping links that include the quality of visitor experiences and sustainable standards in order to valorize local heritage and enhance visitor satisfaction.

Another recurring topic is the relationship between sustainable tourism and traditional food. Local food and local restaurants can play an important role in the sustainable tourism experience [55].

Moreover, the topic of environmental protection and the behaviors of tourists are often afforded in the literature $[103,104]$ since scholars highlight different attitudes in sustainable practices. Tourists pay more attention at home and less during their tourist experience but this negative behavior is unintentional. Hence, other scholars suggest $[71,80,82,105]$ that the governance actors or mangers of the tourism industry have to educate the public on the importance of sustainable practices and protected areas.

This continued focus on education, standards, and models is due to the fact that the "values of conservation, animal welfare, visitor satisfaction, and profitability are often in conflict" [87].

Within this debate, other scholars identify [106-108] the core critical issue represented by the insertion of corporate social responsibility policies in the mass tourism era.

As emerged, the intellectual structure supports and toughens the results of a conceptual structure. Although these papers afford the topic of sustainable tourism according to different perspectives, there are some interesting aspects emerging from the historical direct citation network that have to be deepened.

Indeed, the strength of these articles is connected with the study of different areas of the globe but, often, the interesting studies are not replicated in other destinations.

\section{Conclusions}

Research on sustainable tourism is increasing, but the fast development is quite fragmented. Literature reviews help to consolidate and advance theory and provide insights to address scholars in their efforts. Bibliometric analyses reduce the intrinsic subjectivity of narrative and systematic reviews.

Our study explored state-of-art studies on sustainable tourism. The theoretical and managerial importance of sustainable practices in the tourism industry has led research to explore the interconnection between the precise research stream of sustainable management and its related application in the tourism industry. Different from other bibliometric studies in the tourism domain, we used the conceptual and intellectual structure of the topic. Our contribution to the theory development of the theme under investigation is twofold. First, we described the field through the most relevant citations and, hence, authors. In this way, we provided scholars with a compass for 
orienting future research. Second, we identified and mapped the most recurring themes that show how the topic is developing.

Indeed, the bibliometrical analysis also showed that sustainable tourism development is not only good for preserving the ecological balance of a tourism destination but also for improving its competitiveness.

In this view, tourism policy makers and destination managers should adopt competitive strategies based not only on business-related factors but should also make the sustainability issue a priority in their agenda. What is important to underline is that a competitive and sustainable destination is not only the one that meets the needs of tourists, preserving the natural and cultural local resources, but also increases residents' well-being. Another aspect that emerged from the co-word analysis is the importance of an open innovation approach. The plurality of stakeholders involved not only in the process of co-creation of tourism products but also in the co-production of sustainable tourism policies requires different efforts connected with local governance, the capability of knowledge-sharing, and the degree of local culture on different aspects of destination components $[89,93,95]$. The results also show that actors have to own specific knowledge on either tourism products or local expertise and, contextually, have the capability to provoke innovation. On the other side, local tourism governance has to capture the generated innovation and transform it into policies and best practices for sustainable tourism [93].

Specifically, community engagement, employment opportunities, skill development programs, and public awareness reflect sustainable tourism perception of a host community. So, individuals in the community develop their perceptions regarding destination sustainability, which is reflected through four different sub-dimensions, such as economic, social, cultural, and environmental sustainability [109]. The adoption of an open innovation approach allows the interests of different stakeholders to be balanced to synthetize the needs of local communities and tourists' desires [83]

In the same direction, [110] underlined the importance of the uniqueness of local resources for destination differentiation along with the perception and satisfaction achieved by tourists [93] while bringing the attention to the sensitiveness of natural resources and the necessary limits to be imposed on their usage [111,112]. This is the "environmental paradox", which is that the production of tourism experiences depends on the exploitation of local resources, which, at the same time, must be preserved [113].

In relation to this, [46] states that "what makes a tourism destination truly competitive is its ability to increase tourism expenditure, to increasingly attract visitors, while providing them with satisfying, memorable experiences, and to do so in a profitable way, while enhancing the well-being of destination residents and preserving the natural capital of the destination for future generations."

From the above-mentioned considerations, it is derived that while the role of thte government and industry in creating and shaping destinations is critical to the achievement of sustainability, an important function is also played by marketing strategies that have to be implemented in order to determine how successfully destinations achieve their aims and objectives, in both the short and medium terms. In particular, the idea that tourism marketing and sustainability can perhaps learn from each other may appear counterintuitive. Marketing is generally associated with competitive business strategy, and a profit imperative, promoting consumer choices in a way that advocates the benefits of self-gratification and instant satisfaction, which seems at odds with the ideals of sustainability.

Recalling the added keywords "experience" and "digital" to sustainable tourism and sustainable destination/s, what comes out is the understudied contributions on digital tools in sustainable tourism practices. Indeed, digital technologies can really work on three different pillars of sustainability. Actual contributions on the digital word $[48,49]$ are connected with the promotion or destination image rather than their use as a wider tool of information on the sustainable use of resources, reducing the use of natural resources and connecting people for sharing sustainable practices. Moreover, the word experience is not analyzed as the whole experience lived by tourist/s but rather as a single experience (i.e., food experience, experience with local community, authenticity of local heritage experience, etc.), forgetting that the tourist product is the global lived experience by the tourist [114]. 
Hence, the bibliometrical analysis highlights the necessity to deepen the topic of sustainable tourism with the clear lens of digital and experiential components.

Another interesting aspect emerging from the study is the connection with the marketing activities. Actually, because of the clear difficulties in reconciling sustainability issues with marketing theories in a tourism context, more focused research is needed [115]. From a theoretical point of view, the contributions on marketing need a clear framework recalling the policies both at the induced (phase when the tourist choses the destination, before the arrival) and organic level (stage of the experience in the destination).

From a managerial point of view, there are many innovative solutions to sustainability challenges and there is a growing impetus for the development of more sustainable tourism products that can be marketed successfully. The recall of an open innovation approach is the base of a competitive advantage for both tourist destinations and companies. This represents the synthesis of different interests and a shared willingness to act according to a sustainable manner [116-118].

The limitations of this study should be recognized. The main limitation is the fact that we focused our attention on certain aspects of bibliometric analysis, such as the dataset, and intellectual and conceptual structure (i.e., thematic map, historical direct citation network, literature trends, top journals, most cited journals, etc.). Future research should attempt to examine the social structure (i.e., collaboration network and world map) while also allowing study of the geographical location, deepening the conceptual structure exploration, for example, the type of destination and the type of tourism industry sector. We did not explore these issues at this stage due to the method we decided to adopt. Indeed, we should use ex ante different keywords, but the focus as well as the aim differed from our intention to show the state-of-art on sustainable tourism in the digital and experiential era. Another limitation that provides direction to future research is the fact of exploring whether and to what extent there are differences in diverse kinds of companies within the tourism sector (i.e., hotels, tour operators, travel agencies, destinations, etc.). Further work could examine these features and differences.

Author Contributions: V.D.C, G.D.G. and F.S. conceptualized and supervised research; V.D.C., G.D.G. and F.S. assembled the dataset and sorted literature with the contribution of F.S.; V.D.C., G.D.G. and F.S. carried out statistical analyses; F.S. drafted the manuscript; all authors contributed to the last version of the manuscript.

Funding: This research received no external funding.

Conflicts of Interest: The authors declare no conflict of interests.

\section{References}

1. Lu, J.; Nepal, S.K. Sustainable tourism research: An analysis of papers published in the Journal of Sustainable Tourism. J. Sust. Tour. 2009, 17, 5-16. [CrossRef]

2. Ruhanen, L.; Weiler, B.; Moyle, B.D.; McLennan, C.L.J. Trends and patterns in sustainable tourism research: A 25-year bibliometric analysis. J. Sust. Tour. 2015, 23, 517-535. [CrossRef]

3. Sánchez-Cañizares, S.; Castillo-Canalejo, A.; Cabeza-Ramírez, L. Sustainable tourism in sensitive areas: Bibliometric characterisation and content analysis of specialised literature. Sustainable 2018, 10, 1525. [CrossRef]

4. Higgins-Desbiolles, F.; Carnicelli, S.; Krolikowski, C.; Wijesinghe, G.; Boluk, K. Degrowing tourism: Rethinking tourism. J. Sust. Tour 2019, 1-19. [CrossRef]

5. Hay Mele, B.; Russo, L.; D'Alelio, D. Combining Marine Ecology and Economy to Roadmap the Integrated Coastal Management: A Systematic Literature Review. Sustainable 2019, 11, 4393. [CrossRef]

6. Yoopetch, C.; Nimsai, S. Science mapping the knowledge base on sustainable tourism development, 1990-2018. Sustainable 2019, 11, 3631. [CrossRef]

7. Niñerola, A.; Sánchez-Rebull, M.V.; Hernández-Lara, A.B. Tourism research on sustainability: A bibliometric analysis. Sustainable 2019, 11, 1377. [CrossRef]

8. Garrigos-Simon, F.; Narangajavana-Kaosiri, Y.; Lengua-Lengua, I. Tourism and sustainability: A bibliometric and visualization analysis. Sustainable 2018, 10, 1976. [CrossRef]

9. Bradley, K. Defining digital sustainability. Libr. Trends 2007, 56, 148-163. [CrossRef]

10. Stuermer, M.; Abu-Tayeh, G.; Myrach, T. Digital sustainability: Basic conditions for sustainable digital artifacts and their ecosystems. Sust. Sci. 2017, 12, 247-262. [CrossRef] 
11. Stürmer, M. Characteristics of digital sustainability. In Proceedings of the 8th International Conference on Theory and Practice of Electronic Governance, Guimaraes, Portugal, 27-30 October 2014; ACM: New York, NY, USA, 2014; pp. 494-495.

12. Dapp, M. Open Government Data and Free Software-Cornerstones of a Digital Sustainability Agenda. In The 2013 Open Reader-Stories and Articles Inspired by OKCon 2013: Open Data, Broad, Deep, Connected; 2013. Available online: https://www.researchgate.net/profile/Marcus_Dapp/publication/309792312_ Open_Government_Data_and_Free_Software_-_Cornerstones_of_a_Digital_Sustainability_Agenda/links/ 5823aee808ae61258e3cbf4d.pdf. (accessed on 30 October 2019).

13. Della Corte, V.; Aria, M.; Del Gaudio, G. Smart, open, user innovation and competitive advantage: A model for museums and heritage sites. Mus. Manag. Curatorship 2017, 32, 50-79. [CrossRef]

14. Noël, L.; Carloni, O.; Moreau, N.; Weiser, S. Designing a knowledge-based tourism information system. Int. J. Dig. Cult. Electron. Tour. 2008, 1,1-17. [CrossRef]

15. De Man, A.; Oliveira, C. A stakeholder perspective on heritage branding and digital communication. In Tourism and Culture in the Age of Innovation; Springer: Cham, Switzerland, 2016; pp. 447-455.

16. García, G.C.; Ruiz, I.L.; Gómez-Nieto, M.Á. Tailored platform for the development of NFC tourist services. J. Amb. Int. Smart Environ. 2017, 9, 501-520. [CrossRef]

17. Dickinson, J.E.; Filimonau, V.; Hibbert, J.F.; Cherrett, T.; Davies, N.; Norgate, S.; Winstanley, C. Tourism communities and social ties: The role of online and offline tourist social networks in building social capital and sustainable practice. J. Sust. Tour. 2017, 25, 163-180. [CrossRef]

18. Della Corte, V.; Sciarelli, M.; Cascella, C.; Del Gaudio, G. Customer satisfaction in tourist destination: The case of tourism offer in the city of Naples. J. Invest. Manag. 2015, 4, 39-50. [CrossRef]

19. Bec, A.; Moyle, B.; Timms, K.; Schaffer, V.; Skavronskaya, L.; Little, C. Management of immersive heritage tourism experiencs: A conceptual model. Tour. Manag. 2019, 72, 117-120. [CrossRef]

20. Bassano, C.; Barile, S.; Piciocchi, P.; Spohrer, J.C.; Iandolo, F.; Fisk, R. Storytelling about places: Tourism marketing in the digital age. Cities 2019, 87, 10-20. [CrossRef]

21. Arreeras, T.; Arimura, M.; Asada, T.; Arreeras, S. Association Rule Mining Tourist-Attractive Destinations for the Sustainable Development of a Large Tourism Area in Hokkaido Using Wi-Fi Tracking Data. Sustainable 2019, 11, 3967. [CrossRef]

22. Jung, T.; tom Dieck, M.C.; Lee, H.; Chung, N. Effects of virtual reality and augmented reality on visitor experiences in museum. In Information and Communication Technologies in Tourism; Springer: Cham, Switzerland, 2016; pp. 621-635.

23. D'Hauteserre, A.M. Lessons in managed destination competitiveness: The case of Foxwoods Casino Resort. Tour. Manag. 2000, 21, 23-32.

24. Encalada, L.; Boavida-Portugal, I.; Cardoso Ferreira, C.; Rocha, J. Identifying tourist places of interest based on digital imprints: Towards a sustainable smart city. Sustainability 2017, 9, 2317. [CrossRef]

25. Miah, S.J.; Vu, H.Q.; Gammack, J.; McGrath, M. A big data analytics method for tourist behaviour analysis. Inform. Manag. 2016, 54, 771-785. [CrossRef]

26. Fuchs, M.; Höpken, W.; Lexhagen, M. Big data analytics for knowledge generation in tourism destinations-A case from Sweden. J. Destin. Mark. Manag. 2014, 3, 198-209. [CrossRef]

27. Schnitzer, M.; Seidl, M.; Schlemmer, P.; Peters, M. Analyzing the Coopetition between Tourism and Leisure Suppliers-A Case Study of the Leisure Card Tirol. Sustainability 2018, 10, 1447. [CrossRef]

28. Bae, E.S.; Chang, M.; Park, E.S.; Kim, D.C. The effect of Hallyu on tourism in Korea. J. Open Innov. Technol. Mark. Complex. 2017, 3, 22. [CrossRef]

29. Della Corte, V. Innovation through coopetition: Future directions and new challenges. J. Open Innov. Technol. Mark. Complex. 2018, 4, 47. [CrossRef]

30. Yun, J.; Won, D.; Park, K. Dynamics from open innovation to evolutionary change. J. Open Innov. Technol. Mark. Complex. 2016, 2, 7. [CrossRef]

31. Yun, J.J. How do we conquer the growth limits of capitalism? Schumpeterian Dynamics of Open Innovation. J. Open Innov. Technol. Mark. Complex. 2015, 1, 17. [CrossRef]

32. Yan, M.R.; Chi, H.L.; Yang, J.Y.; Chien, K.M. Towards a City-Based Cultural Ecosystem Service Innovation Framework as Improved Public-Private-Partnership Model-A Case Study of Kaohsiung Dome. J. Open Innov. Technol. Mark. Complex. 2019, 5, 85. [CrossRef] 
33. Yun, J.J.; Jeong, E.; Zhao, X.; Hahm, S.D.; Kim, K. Collective Intelligence: An Emerging World in Open Innovation. Sustainability 2019, 11, 4495. [CrossRef]

34. Yun, J.J.; Liu, Z. Micro-and Macro-Dynamics of Open Innovation with a Quadruple-Helix Model. Sustainability 2019, 11, 3301. [CrossRef]

35. Cuccurullo, C.; Aria, M.; Sarto, F. Foundations and trends in performance management. A twenty-five years bibliometric analysis in business and public administration domains. Scientometrics 2016, 108, 595-611. [CrossRef]

36. Akmal, A.; Podgorodnichenko, N.; Greatbanks, R.; Everett, A.M. Bibliometric analysis of production planning and control (1990-2016). Prod. Plan. Control 2018, 29, 333-351. [CrossRef]

37. Zupic, I.; Čater, T. Bibliometric methods in management and organization. Organ. Res. Meth. 2015, 18, 429-472. [CrossRef]

38. Ramos-Rodríguez, A.R.; Ruíz-Navarro, J. Changes in the intellectual structure of strategic management research: A bibliometric study of the Strategic Management Journal, 1980-2000. Strateg. Manag. J. 2004, 25, 981-1004. [CrossRef]

39. García-Lillo, F.; Úbeda-García, M.; Marco-Lajara, B. The intellectual structure of research in hospitality management: A literature review using bibliometric methods of the journal International Journal of Hospitality Management. Int. J. Hosp. Manag. 2016, 52, 121-130. [CrossRef]

40. Köseoglu, M.A.; Rahimi, R.; Okumus, F.; Liu, J. Bibliometric studies in tourism. Ann. Tour. Res. 2016, 61, $180-198$. [CrossRef]

41. Palmer, A.L.; Sesé, A.; Montaño, J.J. Tourism and statistics: Bibliometric study 1998-2002. Ann. Tour. Res. 2005, 32, 167-178. [CrossRef]

42. Xiao, H.; Smith, S.L. The making of tourism research: Insights from a social sciences journal. Ann. Tour. Res. 2006, 33, 490-507. [CrossRef]

43. Borgman, C.L.; Furner, J. Scholarly communication and bibliometrics. Ann. Rev. Inf. Sci. Technol. 2002, 36, 2-72. [CrossRef]

44. Thelwall, M. Quantitative comparisons of search engine results. J. Am. Soc. Inf. Sci. Technol. 2008, 59, 1702-1710. [CrossRef]

45. Hall, C.M. Publish and perish? Bibliometric analysis, journal ranking and the assessment of research quality in tourism. Tour. Manag. 2011, 32, 16-27. [CrossRef]

46. Benckendorff, P.; Zehrer, A. A network analysis of tourism research. Ann. Tour. Res. 2013, 43, 121-149. [CrossRef]

47. Sheldon, P.J. An authorship analysis of tourism research. Ann. Tour. Res. 1991, 18, 473-484. [CrossRef]

48. Zhao, W.; Ritchie, J.B. An investigation of academic leadership in tourism research: 1985-2004. Tour. Manag. 2007, 28, 476-490. [CrossRef]

49. Li, H.; Ye, Q.; Law, R. Determinants of customer satisfaction in the hotel industry: An application of online review analysis. Asia Pac. J. Tour. Res. 2013, 18, 784-802. [CrossRef]

50. Cheng, M.; Edwards, D.; Darcy, S.; Redfern, K. A tri-method approach to a review of adventure tourism literature: Bibliometric analysis, content analysis, and a quantitative systematic literature review. J. Hosp. Tour. Res. 2018, 42, 997-1020. [CrossRef]

51. Blancas, F.J.; Lozano-Oyola, M.; González, M.; Caballero, R. Sustainable tourism composite indicators: A dynamic evaluation to manage changes in sustainability. J. Sust. Tour. 2016, 24, 1403-1424. [CrossRef]

52. Strandberg, C.; Nath, A.; Hemmatdar, H.; Jahwash, M. Tourism research in the new millennium: A bibliometric review of literature in Tourism and Hospitality Research. Tour. Hosp. Res. 2018, 18, 269-285. [CrossRef]

53. Van Eck, N.J.; Waltman, L. How to normalize cooccurrence data? An analysis of some well-known similarity measures. J. Am. Soc. Inf. Sci. Technol. 2009, 60, 1635-1651.

54. Aria, M.; Cuccurullo, C. bibliometrix: An R-tool for comprehensive science mapping analysis. J. Informet. 2017, 11, 959-975. [CrossRef]

55. Harzing, A.W.; Alakangas, S. Google Scholar, Scopus and the Web of Science: A longitudinal and cross-disciplinary comparison. Scientometrics 2016, 106, 787-804. [CrossRef]

56. Mongeon, P.; Paul-Hus, A. The journal coverage of Web of Science and Scopus: A comparative analysis. Scientometrics 2016, 106, 213-228. [CrossRef]

57. Ritchie, J.R.B.; Crouch, G.I. The Compemitive Destination, a Sustainable Tourism Perspective; Cabi Publishing: Cambridge, UK, 2003.

58. Buhalis, D.; Amaranggana, A. Smart tourism destinations. In Information and Communication Technologies in Tourism 2014; Springer: Cham, Switzerland, 2013; pp. 553-564. 
59. Gretzel, U.; Werthner, H.; Koo, C.; Lamsfus, C. Conceptual foundations for understanding smart tourism ecosystems. Comput. Hum. Behav. 2015, 50, 558-563. [CrossRef]

60. Jovicic, D.Z. From the traditional understanding of tourism destination to the smart tourism destination. Curr. Issues Tour. 2019, 22, 276-282. [CrossRef]

61. Cheng, T.M.; Wu, H.C.; Wang, J.T.M.; Wu, M.R. Community Participation as a mediating factor on residents' attitudes towards sustainable tourism development and their personal environmentally responsible behavior. Curr. Issues Tour. 2019, 22, 1764-1782. [CrossRef]

62. Schiefelbusch, M.; Jain, A.; Schäfer, T.; Müller, D. Transport and tourism: Roadmap to integrated planning developing and assessing integrated travel chains. J. Transprot Geogr. 2007, 15, 94-103. [CrossRef]

63. Tang, S.; Lo, H.K. The impact of public transport policy on the viability and sustainability of mass railway transit-The Hong Kong experience. Trans. Res. Part A Policy Pract. 2008, 42, 563-576. [CrossRef]

64. Bertolini, L.; Le Clercq, F.; Kapoen, L. Sustainable accessibility: A conceptual framework to integrate transport and land use plan-making. Two test-applications in the Netherlands and a reflection on the way forward. Transprot Policy 2005, 12, 207-220. [CrossRef]

65. De Vasconcellos, E.A. Urban change, mobility and transport in São Paulo: Three decades, three cities. Transprot Policy 2005, 12, 91-104. [CrossRef]

66. Sims, R. Food, place and authenticity: Local food and the sustainable tourism experience. J. Sust. Tour. 2009, 17, 321-336. [CrossRef]

67. Okumus, F. Facilitating knowledge management through information technology in hospitality organizations. J. Hosp. Tour. Technol. 2013, 4, 64-80. [CrossRef]

68. Fava Neves, M. The food business environment and the role of China and Brazil building a "food bridge". China Agric. Econ. Rev. 2010, 2, 25-35. [CrossRef]

69. Schmit, T.M.; Rickard, B.J.; Taber, J. Consumer valuation of environmentally friendly production practices in wines, considering asymmetric information and sensory effects. J. Agric. Econ. 2013, 64, 483-504. [CrossRef]

70. Remus, H.; Ovidiu, T.M.; Puiu, N. ECOROM-Indicators System Proposal of Quality Certification in Ecotourism. Amfiteatru Econ. J. 2009, 11, 330-338.

71. Esparon, M.; Gyuris, E.; Stoeckl, N. Does ECO certification deliver benefits? An empirical investigation of visitors' perceptions of the importance of ECO certification's attributes and of operators' performance. J. Sust. Tour. 2014, 22, 148-169. [CrossRef]

72. Ceddia, M.G.; Leonard, D.; Tröster, B. Contribution of international ecotourism to comprehensive economic development and convergence in the Central American and Caribbean region. Appl. Econ. 2018, 50, 3614-3629.

73. Huang, C.C.; Liang, W.Y.; Tseng, T.L.B.; Wong, R.Y. A rough set-based corporate memory for the case of ecotourism. Tour. Manag. 2015, 47, 22-33. [CrossRef]

74. Trunfio, M.; Della Lucia, M. Engaging Destination Stakeholders in the Digital Era: The Best Practice of Italian Regional DMOs. J. Hosp. Tour. Res. 2019, 43, 349-373. [CrossRef]

75. Huang, Y.C.; Liu, C.H.S. Moderating and mediating roles of environmental concern and ecotourism experience for revisit intention. Int. J. Contemp. Hosp. Manag. 2017, 29, 1854-1872. [CrossRef]

76. Liu, C.H.S.; Horng, J.S.; Chou, S.F. A critical evaluation of sustainable tourism from the integrated perspective: Conducting moderated-mediation analysis. Tour. Manag. Perspect. 2015, 16, 43-50. [CrossRef]

77. Pham, N.T.; Tučková, Z.; Jabbour, C.J.C. Greening the hospitality industry: How do green human resource management practices influence organizational citizenship behavior in hotels? A mixed-methods study. Tour. Manag. 2019, 72, 386-399. [CrossRef]

78. Liu, C.W.; Cheng, J.S. Exploring Driving Forces of Innovation in the MSEs: The Case of the Sustainable B\&B Tourism Industry. Sustainable 2018, 10, 3983.

79. Ngo, T.; Lohmann, G.; Hales, R. Collaborative marketing for the sustainable development of community-based tourism enterprises: Voices from the field. J. Sust. Tour. 2018, 26, 1325-1343. [CrossRef]

80. Milman, A. Preserving the cultural identity of a World Heritage Site: The impact of Chichen Itza's souvenir vendors. Int. J. Cult. Tour. Hosp. Res. 2015, 9, 241-260. [CrossRef]

81. Zolfani, S.H.; Sedaghat, M.; Maknoon, R.; Zavadskas, E.K. Sustainable tourism: A comprehensive literature review on frameworks and applications. Econ. Res. Ekon. Istraživanja 2015, 28, 1-30. [CrossRef]

82. Cobo, M.J.; López-Herrera, A.G.; Herrera-Viedma, E.; Herrera, F. Science mapping software tools: Review, analysis, and cooperative study among tools. J. Am. Soc. Inf. Sci. Technol. 2011, 62, 1382-1402. [CrossRef] 
83. Williams, H.A.; Yuan, J.; Williams Jr, R.L. Attributes of memorable gastro-tourists' experiences. J. Hosp. Tour. Res. 2019, 43, 327-348. [CrossRef]

84. Caust, J.; Vecco, M. Is UNESCO World Heritage recognition a blessing or burden? Evidence from developing Asian countries. J. Cult. Herit. 2017, 27, 1-9. [CrossRef]

85. Timothy, D.J.; Boyd, S.W. Heritage Tourism; Pearson Education: Hong Kong, China, 2003.

86. Martini, U.; Buffa, F.; Notaro, S. Community participation, natural resource management and the creation of innovative tourism products: Evidence from Italian networks of reserves in the Alps. Sustainability 2017, 9, 2314. [CrossRef]

87. Higuchi, Y.; Yamanaka, Y. Knowledge sharing between academic researchers and tourism practitioners: A Japanese study of the practical value of embeddedness, trust and co-creation. J. Sustain. Tour. 2017, 25, 1456-1473. [CrossRef]

88. Nilsson, J.H. Urban bicycle tourism: Path dependencies and innovation in Greater Copenhagen. J. Sustain. Tour. 2019, 27, 1-15. [CrossRef]

89. He, Y.; He, P.; Xu, F.; Shi, C. Sustainable tourism modeling: Pricing decisions and evolutionarily stable strategies for competitive tour operators. Tour. Econ. 2019, 25, 779-799. [CrossRef]

90. Teixeira, R.M.; Andreassi, T.; Köseoglu, M.A.; Okumus, F. How do hospitality entrepreneurs use their social networks to access resources? Evidence from the lifecycle of small hospitality enterprises. Int. J. Hosp. Manag. 2019, 79, 158-167. [CrossRef]

91. Prokopis, C.; Avloniti, A.; Farmaki, A. Guests' perceptions of emotionally expressive and non-expressive service providers within the hospitality context. Int. J. Hosp. Manag. 2019, 76, 152-162.

92. Yu, C.P.; Cole, S.T.; Chancellor, C. Assessing community quality of life in the context of tourism development. Appl. Res. Qual. Life 2016, 11, 147-162. [CrossRef]

93. Sakdiyakorn, M.; Sivarak, O. Innovation management in cultural heritage tourism: Experience from the Amphawa waterfront community, Thailand. Asia Pac. J. Tour. Res. 2016, 21, 212-238. [CrossRef]

94. Shone, M.C.; Simmons, D.G.; Dalziel, P. Evolving roles for local government in tourism development: A political economy perspective. J. Sust. Tour. 2016, 24, 1674-1690. [CrossRef]

95. Mikulić, J.; Krešić, D.; Kožić, I. Critical factors of the maritime yachting tourism experience: An impact-asymmetry analysis of principal components. J. Travel Tour. Mark. 2015, 32, S30-S41.

96. Avila-Robinson, A.; Wakabayashi, N. Changes in the structures and directions of destination management and marketing research: A bibliometric mapping study, 2005-2016. J. Destin. Mark. Manag. 2018, 10, 101-111. [CrossRef]

97. Chen, C.F.; Chen, F.S. Experience quality, perceived value, satisfaction and behavioral intentions for heritage tourists. Tour. Manag. 2010, 31, 29-35. [CrossRef]

98. Kastenholz, E.; Eusébio, C.; Carneiro, M.J. Purchase of local products within the rural tourist experience context. Tour. Econ. 2016, 22, 729-748. [CrossRef]

99. Moscardo, G. Mindful visitors: Heritage and tourism. Ann. Tour. Res. 1996, 23, 376-397. [CrossRef]

100. Juvan, E.; Dolnicar, S. The attitude-behaviour gap in sustainable tourism. Ann. Tour. Res. 2014, 48, 76-95. [CrossRef]

101. Rastogi, A.; Hickey, G.M.; Anand, A.; Badola, R.; Hussain, S.A. Wildlife-tourism, local communities and tiger conservation: A village-level study in Corbett Tiger Reserve, India. For. Policy Econ. 2015, 61, 11-19. [CrossRef]

102. Powell, R.B.; Kellert, S.R.; Ham, S.H. Interactional theory and the sustainable nature-based tourism experience. Soc. Nat. Resour. 2009, 22, 761-776. [CrossRef]

103. Reynolds, P.C.; Braithwaite, D. Towards a conceptual framework for wildlife tourism. Tour. Manag. 2001, $22,31-42$. [CrossRef]

104. Weaver, D.B. Asymmetrical dialectics of sustainable tourism: Toward enlightened mass tourism. J. Travel Res. 2014, 53, 131-140. [CrossRef]

105. Hoppen, A.; Brown, L.; Fyall, A. Literary tourism: Opportunities and challenges for the marketing and branding of destinations? J. Destin. Mark. Manag. 2014, 3, 37-47.

106. Santoshkumar, B. Women entrepreneurs in India an emerging face of modern India. J. Indian Manag. Strategy 2015, 20, 15-19. [CrossRef]

107. Cucculelli, M.; Goffi, G. Does sustainability enhance tourism destination competitiveness? Evidence from Italian Destinations of Excellence. J. Clean Prod. 2016, 111, 370-382. [CrossRef]

108. Romão, J.; Guerreiro, J.; Rodrigues, P.M. Territory and sustainable tourism development: A space-time analysis on European regions. Region 2017, 4, 1-17. [CrossRef]

109. Buhalis, D. Marketing the competitive destination of the future. Tour. Manag. 2000, 21, 97-116. [CrossRef] 
110. Buhalis, D. Limits of tourism development in peripheral destinations: Problems and challenges. Tour. Manag. 1999, 20, 183-185.

111. Hassan, S. Determinants of market competitiveness in an environmentally sustainable tourism industry. J. Travel Res. 2000, 38, 239-245. [CrossRef]

112. Williams, P.; Ponsford, I. Confronting tourism's environmental paradox: Transitioning for sustainable tourism. Futyres 2009, 41, 396-404. [CrossRef]

113. Della Corte, V.; Sciarelli, M. Evoluzione del marketing nella filiera turistica: Il ruolo dell'Information \& Communication Technology. In Proceedings of the Congresso Internazionale sulle Tendenze di Marketing, Venice, Italy, 28-29 November 2003; pp. 28-29.

114. Font, X.; McCabe, S. Sustainability and marketing in tourism: Its contexts, paradoxes, approaches, challenges and potential. J. Sust. Tour 2017, 25, 869-883. [CrossRef]

115. Yun, J.J.; Jeong, E.; Yang, J. Open innovation of knowledge cities. J. Open Innov. Technol. Mark. Complex. $2015,1,16$. [CrossRef]

116. Dermody, J.; Yun, J.J.; Della Corte, V. Innovations to advance sustainability behaviours. The Serv. Ind. J. 2019, 39, 1029-1033. [CrossRef]

117. Della Corte, V.; Iavazzi, A.; D'Andrea, C. Customer involvement through social media: The cases of some telecommunication firms. J. Open Innov. Technol. Mark. Complex. 2015, 1, 10. [CrossRef]

118. Ma, L.; Li, T.; Wu, J.; Yan, D. The Impact of E-Hailing Competition on the Urban Taxi Ecosystem and Governance Strategy from a Rent-Seeking Perspective: The China E-Hailing Platform. J. Open Innov. Technol. Mark. Complex. 2018, 4, 35. [CrossRef]

(C) 2019 by the authors. Licensee MDPI, Basel, Switzerland. This article is an open access article distributed under the terms and conditions of the Creative Commons Attribution (CC BY) license (http://creativecommons.org/licenses/by/4.0/). 